Original Article

\title{
The Predictive Value of FDG-PET / CT in Assessing Bone Marrow Involvement in Hodgkin Lymphoma Patients; A Single Center Experience
}

\author{
Hodgkin Lenfoma Hastalarında Kemik İliği Tutulumunu Değerlendirmede \\ FDG-PET/BT'nin Prediktif Değeri: Tek Merkez Deneyimi
}
Merih Reis Aras ${ }^{1}$, Murat Albayrak ${ }^{1}$, Abdülkerim Yıldız², Senem Maral ${ }^{1}$, Hacer Berna Afacan Öztürk ${ }^{1}$, Pınar Akyol ${ }^{1}$, Mesut Tığlıoğlu ${ }^{1}$, Buğra Sağlam¹, Fatma Yılmaz ${ }^{1}$
${ }^{1}$ University of Health Sciences Ankara Dışkapı Yıldırım Beyazıt Training and Research Hospital, Hematology Department, Ankara, Türkiye
${ }^{2}$ Ministry of Health Hitit University Erol Olçok Training and Research Hospital, Hematology Department, Çorum, Türkiye

\begin{abstract}
Purpose: This study was conducted to determine the predictive value of positron emission tomography (PET/CT) used in staging Hodgkin Lymphoma (HL) at the time of diagnosis in determining bone marrow (BM) involvement.

Material and method: The patients diagnosed with Hodgkin lymphoma in our hematology department between 2009-2019 were analyzed retrospectively. The study included a total of 46 patients who underwent both BM biopsy and PET/CT for staging at the time of diagnosis.

Results: The mean age of the 46 patients was 40 years (19-80). BM involvement was determined in three patients from BM biopsy and in 14 patients from PET/CT performed at the time of diagnosis. When PET/CT results were analyzed according to BM biopsy results, it was found that the sensitivity was $100 \%$ (3/3) and the specificity was $74.4 \%(32 / 43)$.

Conclusion: The sensitivity of PET/CT is very high in detecting BM involvement in HL patients, and is a non-invasive test. However, in doubtful cases it may be more appropriate to perform a BM biopsy, even though it is invasive, as PET/CT may cause false positive patient staging due to its low specificity.
\end{abstract}

Keywords: Hodgkin lymphoma, bone marrow involvement, PET/CT

\section{ÖZET}

Giriş ve Amaç: Hodgkin Lenfoma hastalarında tanı anında evrelemede kullanılan PET/BT tetkikinin kemik iliği tutulumunu belirlemedeki yerini saptamak

Yöntem ve Gereçler: Sağlık Bilimleri Üniversitesi Ankara Dışkapı Yıldırım Beyazıt Eğitim ve Araştırma Hastanesi Hematoloji kliniğinde 2009-2019 yılları arasında takip edilen Hodgkin lenfoma tanılı hastaların dosyaları retrospektif olarak incelendi. Bu hastalar arasında tanı anında hem kemik iliği biyopsisi yapılan, hem de PET/BT çekilen toplam 46 hasta çalışmaya dahil edildi.

Bulgular: Toplam 46 hastanın yaş ortalaması 40 (19-80) idi. Hastaların kemik iliği tutulum durumları incelendiğinde kemik iliği biyopsisinde üç hastada tutulum saptanırken, tanı anında yapılan PET/BT'de 14 hastada tutulum olduğu görülmüştür. PET/BT sonuçlarının kemik iliği biyopsi sonuçlarına göre değerlendirildiğinde duyarlılığının \%100 (3/3), özgüllüğünün ise $\% 74,4(32 / 43)$ olduğu görüldü. 
Tartışma ve Sonuç: Hodgkin lenfoma hastalarında kemik iliği tutulumunu saptamada non invaziv bir test olan PET/BT'nin duyarlılığı çok yüksektir. Ancak özgüllüğünün düşük olmas1 sebebi ile yanlış pozitif hasta evrelemesine sebep olabileceğinden şüphe halinde invaziv de olsa kemik iliği biyopsisi yapılması daha uygun olacaktır.

Anahtar Kelimeler: Hodgkin Lenfoma, kemik iliği tutulumu, PET/BT

\section{Introduction}

Hodgkin lymphoma (HL) is a lymphoid malignancy originating from B cells [1], which accounts for approximately $12 \%$ of all lymphomas [2]. In histomorphological classification it is divided into two major groups; classical type and nodular lymphocyte predominant (NLP) type. Classical type HL includes nodular sclerosis (NS), mixed cellularity (MC), lymphocyte rich (LR) and lymphocyte depleted (LD) subtypes [1].

Approximately $90 \%$ of cases are classical type HL patients. NS type is the most common subtype of classical HL. Although the average age at diagnosis varies between 20 and 34 years, differences can be detected between ethnic groups. It is generally seen more frequently in males than females. As with most other hematological malignancies, one of the most important prognostic markers in HL patients is stage. Correct staging of patients at the time of diagnosis plays a major role in the future management of patients. The Ann-Arbor classification with Cotswold modification is still used for staging HL [3].

With Cotswold modification, liver biopsy and laparotomy are removed from the routine staging of HL patients, while another invasive procedure, bone marrow (BM) biopsy, is still performed for staging [4]. Stage I-II is defined as early stage and stage III-IV as advanced stage disease [5]. Even if BM involvement exists alone, it advances the stage and therefore has significant impact on the treatment and prognosis [6].

$\mathrm{BM}$ involvement is an indicator of generalized disease since these cases are regarded as stage IV regardless of lymph node involvement.
Although BM biopsy has been accepted as the gold standard to detect the involvement of BM since the 1970s, it is an invasive procedure and can cause some serious complications [4].

However, fluorodeoxyglucose (FDG) PET/CT has recently been the subject of research on the topic of determining $\mathrm{BM}$ involvement [6]. In the last 20 years, FDG / PET-CT has been used extensively for staging lymphomas. Several studies have retrospectively investigated the use of PET-CT to detect BM involvement, and have reported that FDG/PET-CT showed superior sensitivity compared to BM biopsy. Of these studies, Tzu-Hua et al[7] showed the sensitivity of PET / CT to be $96.8 \%$, whereas the sensitivity of BM biopsy was $32.3 \%$. In another study, Weiler-Sagie et al[8] reported PET-CT sensitivity as $97 \%$, and the sensitivity of BM biopsy as $15 \%$. According to the results of the German Hodgkin working group, PET-CT performed at the time of diagnosis was reported to describe the involvement of BM with high sensitivity proved by BM biopsy. With excellent negative predictive value, PET is a very accurate and reliable tool for excluding BM involvement. [4].

The aim of this study was to determine the role of PET/CT examination used in staging at the time of diagnosis in determining $\mathrm{BM}$ involvement in HL patients diagnosed in our center.

\section{Patients and methods}

A retrospective evaluation was made of patients with HL diagnosed in the Hematology 
Table 1. Demographic and clinical features of patients

\begin{tabular}{lcc}
\hline Variable (N=46) & & $(\mathrm{n}, \%)$ \\
\hline Disease subtype & & \\
& LR & $4(8.7)$ \\
& MC & $11(23.9)$ \\
& NLP & $7(15.2)$ \\
& NS & $24(52.2)$
\end{tabular}

\begin{tabular}{ll}
\hline $\begin{array}{l}\text { Age at diagnosis } \\
\text { (median, years) }\end{array}$ & $40.0[19.0-80.0]$ \\
\hline Gender
\end{tabular}

\begin{tabular}{rrc} 
Male & $25(54.3)$ \\
Female & $21(45.7)$ \\
\hline Stage at diagnosis & & \\
& I & $2(4.3)$ \\
& II & $26(56.6)$ \\
III & $14(30.4)$ \\
& IV & $4(8.7)$
\end{tabular}

LR: Lymphocyte rich, MC:Mixed cellularity, NLP:Nodular lymphocyte predominant, NS:Nodular sclerosis

Clinic of the University of Health Sciences Ankara Diskapı Yildirim Beyazit Training and Research Hospital in the period 20092019. Of these patients, 46 who underwent both BM biopsy and PET/CT at the time of diagnosis were included in the study. Patients who had only BM biopsy or PET-CT at the time of diagnosis were excluded from the study. Age, gender, HL type and subtype, and disease stage were recorded. BM biopsy was considered the gold standard for the detection of involvement.

\section{Statistical analysis}

Study data were analyzed using SPSS 24 software. Descriptive statistics and frequency tables were used. Descriptive data were given as a percentage. Negative predictive and positive predictive values, sensitivity and specificity values were calculated.

Ethical approval and informed consent

All procedures performed in studies involving human participants were in accordance with the ethical standards of the institutional and/or national research committee and with the 1964 Helsinki Declaration and its later amendments or comparable ethical standards. As a standard of care/action of our hospital, the patient records confirmed that all the study patients gave informed consent at the time of hospitalization and before the administration of any intervention. The study was approved by University of Health Sciences Turkey, Ankara Dışkapı Yıldırım Beyazit Training and Research Hospital Ethics Committee (protocol no: 90/05, date: 22.06.2020).

\section{Results}

Of the $46 \mathrm{HL}$ patients included in the study, $25(54.3 \%)$ were male and $21(45.7 \%)$ were female. The median age at diagnosis was 40.0 years (19.0-80.0). $84.8 \%$ of the patients were classical type HL and $15.2 \%$ were NLP type HL. The most common subtype in patients with classical type HL was NS in 24 (52.2\%) patients. Other subtypes were $\mathrm{MC}$ in 11 (23.9\%) patients and LR in four $(8.7 \%)$ patients. No patient with LD subtype was detected. At the time of diagnosis, $28(60.9 \%)$ patients were early stage (stage I-II), and 18 (39.1\%) were advanced stage (stage III-IV). The demographic and clinical features of the patients are given in Table 1. When the BM involvement status of the patients was examined, involvement was detected in three patients in BM biopsy, and PET/CT showed increased uptake of FDG in 14 patients, demonstrating involvement at the time of diagnosis. BM involvement rates according to the diagnostic methods are given in Table 2. As a result of the analyses made by comparing the results according to the results of $\mathrm{BM}$ biopsy, the sensitivity of the PET / CT method in terms of BM involvement was $100 \%(3 / 3)$ and specificity was $74.4 \%$ (32/43) (Table 3).

\section{Discussion}

All HL patients should be staged during diagnosis to determine the appropriate treatment protocol and prognosis. History, physical examination, radiological imaging, and BM biopsy are part of the routine staging 
Table 2. Bone marrow involvement rates according to diagnostic methods

\begin{tabular}{|c|c|c|c|c|}
\hline \multirow[t]{2}{*}{$(\mathrm{N}=46)$} & & \multicolumn{2}{|c|}{$\begin{array}{l}\text { Bone marrow involvement in bone } \\
\text { marrow biopsy }\end{array}$} & \multirow[b]{2}{*}{ Total } \\
\hline & & $(+)(n)$ & $(-)(n)$ & \\
\hline \multirow{2}{*}{$\begin{array}{l}\text { Bone marrow } \\
\text { involvement in } \\
\mathrm{PET/CT}\end{array}$} & $(+)(n)$ & 3 & 11 & 14 \\
\hline & $(-)(n)$ & 0 & 32 & 32 \\
\hline Total & & 3 & 43 & 46 \\
\hline
\end{tabular}

Table 3. PET/CT sensitivity, specificity and positive-negative predictive values

\begin{tabular}{lcc}
\hline & Value & \%95 confidence interval \\
\hline Sensitivity & $\% 100$ & $29.24-100$ \\
\hline Spesificity & $\% 74.42$ & $58.83-86.48$ \\
\hline Positive predictive value & $\% 21.43$ & $14.08-31.23$ \\
\hline Negative predictive value & $\% 100$ & \\
\hline
\end{tabular}

process $[9,10]$. Correct staging is important to be able to determine the appropriate treatment protocol. In addition, it is important in terms of side-effects and reducing toxicity [11]. BM involvement in HL patients is compatible with stage 4 disease. Although BM involvement rates vary according to the developmental level of countries, it is seen in approximately $10 \%$ of the adult population. $[9,10]$ In the current study, BM involvement was observed in three patients $(6.5 \%)$ according to the histopathological findings.

$\mathrm{BM}$ biopsy is an invasive procedure used to diagnose a large number of hematological diseases and to evaluate treatment response. The posterior iliac crest is considered the most suitable region for biopsy. The frequency of complications is very low during and after this procedure $(0.05 \%)$. The most common complication is bleeding.[12] Other compli- cations can be listed as local infection at the biopsy site and needle breakage during the procedure. More rarely, transient neuropathy accompanied by gluteal compartment syndrome secondary to bleeding at the biopsy site may occur. In addition, patients with osteoporosis or osteomyelitis are at risk of bone fracture at the biopsy site. [12-14]

Since the procedure is invasive and there is a slight risk of the complications mentioned above, other methods that can be used instead of this procedure have been the subject of research. The first of these is the PET/CT method, which is currently used very often for staging. PET/CT is widely used in the initial staging of patients diagnosed with lymphoma and in evaluating the response to treatment. [11] In addition, it has high sensitivity and specificity in detecting extranodal involvement.[6] In this study, in which it was 
aimed to determine the potential role of PET $\mathrm{CT}$ in detecting BM involvement at the time of diagnosis in HL patients, the negative predictive value and sensitivity of PET-CT was $100 \%$ and specificity was $74 \%$. Eser A. et al.[15] analysed 104 patients with HL and the negative predictive value and sensitivity of PET-CT was reported to be $100 \%$ and specificity was $68.9 \%$. In a study by Muzahir S. et al. [11] 122 patients diagnosed with HL were evaluated. The sensitivity of PET-CT was reported as $100 \%$, specificity as $76.5 \%$ and the negative predictive value was $76.5 \%$ in terms of BM involvement.

Considering the data of the current study and other data in the literature, it can be seen that the sensitivity of PET / CT is quite high but the specificity is relatively low. The reason for this can be interpreted in several aspects. In PET-CT examination, 18F-FDG (a glucose analog) is taken into the cell with glucose transporter protein. Malignant cells have higher metabolic rates and express a greater number of specific membrane proteins than normal cells. As a result, 18F-FDG is taken up more by tumor cells. This is the basis of the FDG-PET imaging method. [16] As PET-CT is primarily a glucose measurement, it can give false positive results in cases where there is increased BM activity. Increased

\section{REFERENCES}

1. Küppers R, Engert A and Hansmann M-L. Hodgkin lymphoma. The Journal of Clinical Investigation. 2012; 122: 3439-47.

2. Vale RHBd, Ferraro DA, Duarte PS, et al. Bone marrow uptake of 18F-fluorodeoxyglucose in Hodgkin lymphoma without bone involvement: comparison between patients with and without $B$ symptoms. Radiologia Brasileira. 2018; 51: 78-80. 3. Shanbhag $\mathrm{S}$ and Ambinder RF. Hodgkin lymphoma: a review and update on recent inflammatory markers, and inflammatory changes in the BM are examples of these conditions. Diffuse involvement may be associated with myeloid activation, which may also help to explain the low specificity of PET-CT in detecting BM involvement. [17] In addition, increased involvement in the sacral region may be observed in patients with $B$ symptoms due to increased cytokine production. [2] Although the possibility is low, if PET/CT imaging were to be performed after BM biopsy, there could be a false increased involvement in the biopsy site.[18]

The limitations of this study are that it was performed retrospectively and with a limited number of patients. There is a need for further prospective studies with more patients.

\section{Conclusion}

The PET/CT method has high sensitivity in detecting the BM involvement of HL patients. Therefore, in patients with no BM involvement on PET-CT, there can be considered to be no need for the invasive and painful procedure of biopsy. However, since it may cause false positive staging due to low specificity, it will be more appropriate to perform BM biopsy in cases of high suspicion even though it is an invasive procedure.

progress. CA: a Cancer Journal for Clinicians. 2018; 68: 116-32.

4. Voltin C-A, Goergen H, Baues $C$, et al. Value of bone marrow biopsy in Hodgkin lymphoma patients staged by FDG PET: results from the German Hodgkin Study Group trials HD16, HD17, and HD18. Annals of Oncology. 2018; 29: 1926-31.

5. Cheson BD, Fisher RI, Barrington SF, et al. Recommendations for initial evaluation, staging, and response assessment of Hodgkin and nonHodgkin lymphoma: the Lugano classification. Journal of Clinical Oncology. 2014; 32: 3059. 
6. Özpolat HT, Yilmaz E, Goksoy HS, et al. Detection of bone marrow involvement with FDG $\mathrm{PET} / \mathrm{CT}$ in patients with newly diagnosed lymphoma. Blood Research. 2018; 53: 281-7.

7. Chen-Liang TH, Martin-Santos T, Jerez A, et al. The role of bone marrow biopsy and FDG$\mathrm{PET} / \mathrm{CT}$ in identifying bone marrow infiltration in the initial diagnosis of high grade non-Hodgkin Bcell lymphoma and Hodgkin lymphoma. accuracy in a multicenter series of 372 patients. American Journal of Hematology. 2015; 90: 686-90.

8. Weiler-Sagie M, Kagna O, Dann EJ, BenBarak $A$ and Israel $\mathrm{O}$. Characterizing bone marrow involvement in Hodgkin's lymphoma by FDGPET/CT. European Journal of Nuclear Medicine and Molecular Imaging. 2014; 41: 1133-40.

9. Chauhan K, Jain M, Shukla P and Grover RK. Bone marrow involvement in Hodgkin's lymphoma: Data from a cancer hospital. Clinical Cancer Investigation Journal. 2016; 5: 516.

10. Howell SJ, Grey M, Chang J, et al. The value of bone marrow examination in the staging of Hodgkin's lymphoma: a review of 955 cases seen in a regional cancer centre. British Journal of Haematology. 2002; 119: 408-11.

11. Muzahir S, Mian M, Munir I, et al. Clinical utility of 18F FDG-PET/CT in the detection of bone marrow disease in Hodgkin's lymphoma. The British Journal of Radiology. 2012; 85: e490-e6.

12. Berber I, Erkurt MA, Kuku I, et al. An unexpected complication of bone marrow

Corresponding author e-mail: merihreis@gmail.com

Orcid ID:

Merih Reis Aras 0000-0002-9161-5582

Murat Albayrak 0000-0003-4025-741X

Abdulkerim Yıldız 0000-0002-9596-4042

Senem Maral 0000-0003-4766-1861

Hacer Berna Afacan Öztürk 0000-0001-9386-7604

Pinar Akyol 0000-0003-3829-289X

Mesut Tığlıoğlu 0000-0002-4111-2004

Buğra Sağlam 0000-0001-8342-990X

Fatma Yılmaz 0000-0001-6112-3950 aspiration and trephine biopsy: arteriovenous fistula. Medical Principles and Practice. 2014; 23: 380-3.

13. Bain B. Bone marrow biopsy morbidity: review of 2003. Journal of Clinical Pathology. 2005; 58: 406-8.

14. Roth JS and Newman EC. Gluteal compartment syndrome and sciatica after bone marrow biopsy: a case report and review of the literature. The American Surgeon. 2002; 68: 791. 15. Eser A, Tanrikulu FP, Sezgin A and Tuglular AT. The Role of PET/CT to Detect Bone Marrow Involvement in Hodgkin Lymphoma. Bezmialem Science. 2019; 7: 95-100.

16. Long NM and Smith CS. Causes and imaging features of false positives and false negatives on $18 \mathrm{~F}-\mathrm{PET} / \mathrm{CT}$ in oncologic imaging. Insights into imaging. 2011; 2: 679-98.

17. Salaun $P$, Gastinne T, Bodet-Milin C, et al. Analysis of FDG PET diffuse bone marrow uptake (BMU) and splenic uptake (SU) in staging of Hodgkin lymphoma $(\mathrm{HL})$ : A reflect of disease infiltration or just inflammation? European Journal of Nuclear Medicine Imaging. 2009; 36: 1813-21.

18. Minnema MC and de Keizer B. Falsepositive PET scan after bone marrow biopsy. British Journal of Haematology. 2013; 161: 753-.

Doi: 10.5505/aot.2021.08941 